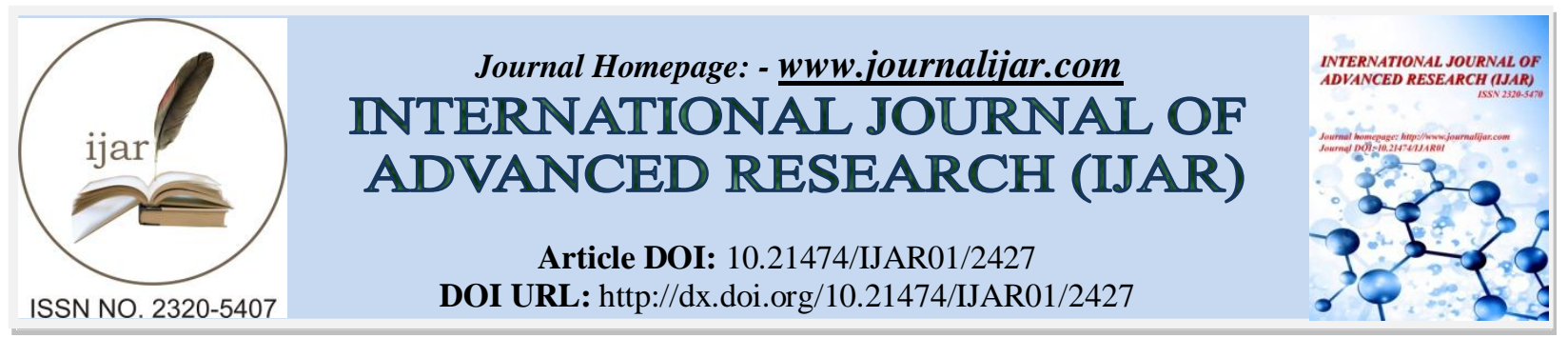

RESEARCH ARTICLE

\title{
A STUDY OF OUTCOMES OF THE DIVINEGUMA POVERTY ALLEVIATION PROGRAMME IN BATTICALOA DISTRICT OF SRI LANKA.
}

\author{
Mr V. Navirathan. \\ Senior Asst. Registrar, Eastern University, Sri Lanka.
}

\section{Manuscript Info \\ Manuscript History}

Received: 20 October 2016

Final Accepted: 22 November 2016

Published: December 2016

Key words:-

Poverty alleviation, Divineguma, livelihood

Program, Outcomes

\section{Abstract}

This paper evaluates the Divineguma Programme as a national poverty reduction policy in Sri Lanka.

Divi Neguma Programme was commenced at National Level, converting into reality, the concept of creating a prosperous village brimming with resources through livelihood and social development by the year 2016, as envisaged in the "Mahinda Chinthana- Vision for the future", the pilot force of the present Government and Budget Proposals-2011. This study was an attempt to identify the outcomes of newly introduced poverty reduction strategy in Sri Lanka. The objective of this study is to examine whether the Poverty alleviation Programme increase the income level of the beneficiaries in Batticaloa District and examine whether the contribution of Poverty alleviation Programme to increase the standard of living of the beneficiaries living in the District.

Therefore, the major purpose of this study are analysis of outcomes of Divineguma programme and lessons learn to future economic development program which could be implemented efficient, effective and economically.

Copy Right, IJAR, 2016,. All rights reserved.

\section{Introduction:-}

The government of Sri Lanka has a long history of program and interventions aimed at developing its rural areas. Despite the efforts of these activities Sri Lanka also has certain under developed areas too. Rural areas suffer from production deficiency, lack of basic infrastructure, informal and scattered small scale enterprises and a high dependence on climate conditions for securing their livelihoods which in turn makes life risky and difficult to plan ahead.

The Divineguma program, one of the major poverty alleviation and development program in Sri Lanka, has been in operation since 2011. Poverty is considered to be the greatest threat and challenge to development and peace. It is the route cause of many conflicts that threaten to tear apart society.

The poverty alleviation program in Sri Lanka are implemented according to consumption based or production based or both. The Divineguma program mainly focuses on improve the production to empower the rural people.

Poverty means the inability of an individual to secure the most basic human needs. Poverty reduction has now become one of the millennium development goals in the development discourse. The problem o f poverty in Sri 
Lanka has also been evident even before and after independence. The government of Sri Lanka allocates a considerable percentage of the annual budget for this national poverty reduction program. Similarity the problem of poverty has been given the highest priority in the policy agenda by every government in Sri Lanka. At their election campaigns, major political parties have given a number of promises focusing on the poor thereby the issue has been given a higher political attention. For the last four decades, all successive government has introduced several policies to address the poverty problem prior to this program. However, there is evidence that poverty still remains at a considerable level.

The current study focuses mainly on development activities of Divineguma program and therefore, this study evaluates the impact and outcomes of the Divineguma program.

\section{Literature Review:-}

"Don't ask me what poverty is because you have met it outside my house. Look at the house and count the number of holes. Look at my utensils and the clothes that I am wearing. Look at everything and write what you see. What you see is poverty".

- A poor man. Kenya 1997 (Central Bank Report-2015)

Poverty is the state of being without the necessities of daily living, often associated with need, hardship and lack of resources across a wide range of circumstances. Poverty alleviation through rural development is an important part of the development in a country.

The successive government of Sri Lanka implemented number of poverty alleviation program since independence. Despite many challenges and difficulties in the past the quality of life of people after six decades of independence has improved considerably, and state sponsored free education, free school uniform, mid-day meal, free book, free health service, housing schemes, model village scheme, food stamp scheme, Mahapola scholarship, Janasavia program, Samurdhi program and Divineguma program are some of the poverty alleviation and rural development program adopted by successive government of Sri Lanka in the past and some of them are in progress.

\section{Poverty reduction strategy in Sri Lanka:-}

Sri Lanka articulated a poverty reduction strategy in 2003 which focused on restoring peace and economic growth in country. Its main pillars are;

- Strengthening the Economy

- Reducing poverty caused by conflict

- Creating opportunities for the poor to participate in economic growth

- Investing in people

- Empowering the poor

- Implementing an effective monitoring and evaluation system (www.worldbank.lk)

Fernando, R.L.S. (2010) indicated that Samurdhi became the largest government social assistant program in 1995, when it replaced the Janasaviya program. The philosophy of Samurdhi is based on the acceptance of the fact that every individual has a potential that has to be utilize for their wellbeing. The mission of the Samurdhi policy is to ensure the country's prosperity through poverty alleviation, job creation and development of human resources among the poor through proper investment in health, education and vocational training. The main objectives of this program are to provide a solution to the problem of an employment which is the most pressing problem among the youth, eradication of the poverty from the country at large and obtaining the direct participation in the development.

In 2011, the government has introduced Divineguma program to sustainable development in rural areas of the country. This program is primarily intended to ensure the empowerment of the people of this country through development of home garden there by enabling the people to produce adequate qualities of vegetables and a variety of crops of good nutritional values and also to earn an additional income through the improvement of domestically produce goods.

Besides these, the said program is expected to create new income generation opportunities through agriculture and livestock development and promotion of export crops and domestic industries at commercial level and also to 
upgrade the economic standard of the people and to encourage them to supply their produce targeting market requirements. (Circular No: SP/SB/02/11 of Presidential Secretariat)

\section{Rural Development:-}

Singh (1999: 21) defines rural development as a process leading to sustainable improvement in the quality of life of rural people, especially the poor. In other words, rural development is perceived as a positive change of conditions for the people concerned.

Ellis (2000:25) defines rural development as: "an organizing principle for antipoverty policies in rural areas of low income countries rural development emphasizes an action or a change to develop or improve a rural area to the benefit of the people residing there".

\section{Livelihood:-}

Ellis(2000:10) define the livelihood comprises the assets (natural, physical, human, financial and social capital) the activities and the access to these (mediated by institutions and social relations) that together determine the living gained by the individual of household.

Important of this Study:-

Poverty is the state of human beings who are poor. That is they have little or no material means of surviving little or no food, shelter clothes, healthcare education and other physical means of living and improving one's life. Poverty reduction measures target to improve living standards of poor. Poverty alleviation also involves improving the living conditions of people who are already poor. Therefore, efficient poverty alleviation policies and development programmes could be identified from this study.

\section{Statement of the Problem:-}

Even several poverty alleviation programmes were implemented in the district from time to time; the people are facing very difficult to live comfortably.

The research problem is what the impacts are caused by the poverty alleviation program in the enlistment on the standard of the beneficiaries of the Batticaloa District.

\section{Objectives of the study:-}

To make this study very effective the following objectives are listed.

- To study status of households before and after Divineguma program in Sri Lanka

- To examine the livelihood security status of poor people in Sri Lanka

- To identify the socio economic condition of Sri Lanka

- To make sure lesson learned for the future development programmes.

\section{Hypothesis:-}

Following hypotheses have been proposed and tested in the study.

- Divineguma program positively impact income of the beneficiaries in Batticaloa District.

- Divineguma program promotes the effectiveness of living standard in Batticaloa District

\section{Research Methodology:-}

A research design was developed to explore through choice of the study areas ,sampling techniques, data collection, and descriptive studies by the researcher. The following section describes the research design of the study.

Eastern province comprises of three districts Batticaloa, Ampara and Trincomalee. It has about $1000 \mathrm{~km}$ of coastline and 2378 villages are established in the province. Batticaloa district were selected for this study to identify the economic patterns of the families. For that, the study areas of the research are Vaharai, Kiran and Kaluwanchikudy Divisional Secretariat divisions which are the villages of Batticaloa district in eastern Sri Lanka.

Ten villages were selected for this study in the selected Divisional Secretariat. The main aim of this research is to study the outcomes of the Divineguma program in Batticaloa district of Eastern Sri Lanka. I have decided to select families of various income level. 
A sample of 100 households were selected randomly from ten villages. 10 respondents were interviewed from each village. Stratified sampling plan and two sample model were used.

Sample size:-

\begin{tabular}{|l|l|l|}
\hline Number of DivinegumaVillage & No of Households & Sample \\
\hline 10 & 5206 & 100 \\
\hline
\end{tabular}

\section{Data to be gathered:-}

Data and information collection from primary and secondary sources:-

Considering the nature of the research both primary and secondary data were collected for this study. The primary data was collected through observation, interview and questionnaire. The secondary data was collected through materials including statistics, research work, study reports. These include available data and information about various socio-economic aspects and previous as well as current development schemes. It noted that various socioeconomic aspects of the study area have considered comprehensively without any bias towards any of the aspect. As Census data is relatively inexpensive and highly reliable, Census represents one of the main secondary sources of data and information.

\section{Results and Discussion:-}

The 100 samples had been analyzed and evaluated on research variable of Income, Saving, Well being, Capacity Improvement, Coping with vulnerability, Employment, Gender balance and Livelihood.

\begin{tabular}{|c|c|c|c|}
\hline Dependent Variable & $\mathbf{R}$ & R Square & Regression \\
\hline Income & 0.690 & 0.476 & 4.653 \\
\hline Saving & 0.726 & 0.527 & 5.153 \\
\hline Well Being & 0.699 & 0.488 & 4.769 \\
\hline Coping with Vulnerability & 0.004 & 0.000 & 0.000 \\
\hline Entrepreneurial Skill and Personality Development & 0.498 & 0.248 & 2.424 \\
\hline Employment & 0.143 & 0.021 & 0.201 \\
\hline Gender Balance & 0.608 & 0.370 & 3.610 \\
\hline Livelihood & 0.300 & 0.090 & 0.881 \\
\hline
\end{tabular}

According to the above above analytical outputs there is a strong positive relationship between Divineguma Poverty alleviation Program and Income ,Saving, Well being ,Entrepreneurial Skill and Personality Development, Gender Balance and Livelihood development as $\mathrm{R}$ is more than 0.3 for above independents variables.

\begin{tabular}{|c|c|c|c|c|c|c|c|c|}
\hline \multicolumn{9}{|c|}{ Coefficients $^{\mathrm{a}}$} \\
\hline \multirow{2}{*}{\multicolumn{2}{|c|}{ Model }} & \multicolumn{2}{|c|}{ Unstandardized coefficients } & \multirow{2}{*}{$\begin{array}{c}\begin{array}{l}\text { Standardized } \\
\text { Coefficients }\end{array} \\
\text { Beta }\end{array}$} & \multirow[t]{2}{*}{$\mathrm{t}$} & \multirow[t]{2}{*}{ Sig. } & \multicolumn{2}{|c|}{ 95.0\% Confidence Interval for B } \\
\hline & & $\mathrm{B}$ & Std. Error & & & & Lower Bound & Upper Bound \\
\hline 1 & (Constant) & 1.706 & .138 & & 12.408 & .000 & 1.433 & 1.979 \\
\hline & Income & .430 & .046 & .690 & 9.442 & .000 & .339 & .520 \\
\hline
\end{tabular}

The coefficient of the model is highly significant at $5 \%$ of significant level. So X variable ( Income) highly influence in Y (Poverty alleviation ).

\section{Recommendation and Suggestions:-}

According to the study there are number of causes have affected on the poverty situation of the area. To overcome the situation it is important to address these key problems.

1. Increase income generating activities

2. Solve the agricultural related problems

3. Introduced new crops varieties which use less water

4. Create new employment opportunities

5. Give vocational trainings for the younger generation

6. Provide awareness program about the Divineguma program

7. Increase the loan facilities and encourage the poor to take loan 
8. Make guidance to start self employment

9. Introduced the housing loan schemes

10. Provide a big push to the poor families

11. Increase the benefits for short term

12. Suitable project proposal should be approved

There are some weaknesses in the selection process. So it could be improved by the following suggestions. Beneficiaries selection should be done by the panel. This could be consists of divisional secretary, grama Niladhari and representative of the people. Divineguma beneficiaries list of each village should be published in the respective villages, so that the public could be able to see the list and inform the Grama Niladhari if there is any wrong person included in the beneficiaries list.

Project proposals should be prepared according to the availability of resources in the area. Appoint an officer specifically to monitoring the process of issuing stamps to the correct beneficiaries. Appoint an officer to ensure that the multipurpose cooperative society is issuing correct quality and quantity of commodities to the beneficiaries. Government should give instructions to the respective heads.

Strict regulation should be adopted to submit the reports every month and on time. They would be punished if they fail to do. Same reporting method should be adopted by the officers who involved in the poverty alleviation program. Training should be provided about the preparation of reporting for the relevant officers. Staff officers should provide adequate feed back to the officers engage in the poverty alleviation program.

Finally, poverty can be affect any time any people. Behind poverty there are multiple reasons can be identified. According to the study, Divineguma poverty alleviation program has significant influence on poverty alleviation and rural development. The rural poverty alleviation is one of the most important things for the country's development process. Rural poor are always living in the vulnerable situation. Therefore it is important to pay special attention on rural poor people to improve their living standard and development.

\section{References:-}

1. Abdrabo., M.A, \& M. A. Hassaan, A,2003, Manual For Socioeconomic Study, Centre for Environment and Development for the Arab Region and Europe, (Cedare).

2. Ministry of Economic Development , 2012 , Performance Report.

3. Drinkwater, M. \& McEwan, M., 1992, Household food security and environmental sustainability in farming systems research: developing sustainable livelihoods. Paper presented to the Adaptive Planning Research Team Bi-annual Review Meeting, Mangu, Zambia.

4. Frankenberger,T.R., and M.K. McCaston,1998, the household livelihood security concept, $\mathrm{ftp} / / / \mathrm{ftp}$. fao.org/docrep/fao/X0051t/X0051t05.pdf Date: 28.05.2011

5. Margo Keizer, 2004, Social Quality and the Component of Socio-economic security, European Foundation on Social Quality, The Netherlands, pp.14-19.

6. Ministry of Finance and Planning, 2011, Poverty Indicators, Household Income and Expenditure Survey 2009/10, Department of Census and Statistics, Sri Lanka

7. Michael P.Todaro, "Economic development", Addison Wesley loggman, Singapore $7^{\text {th }}$ Edition (2001), Pages 192-235.

8. W.G Mithratne, “Triple Development Approach of Samurdhi Programme,” Sri Lanka Samurdhi Authority. 2000

9. W.G Mithratne, “Samurdhi Bank Union Movement to Empower the poor Community”, Sri Lanka Samurdhi Authority,2000.

10. Department of and Statistics Presidential Secretariat, Sri Lanka "Statistical abstract-2005",

11. Centre for information resource management (CIRM), "Vulnerability-Poverty index, Batticaloa District" 